IZA DP No. 6722

Do Fiscal and Political Decentralization Raise Students' Performance? A Cross-Country Analysis

Luis Diaz-Serrano

Enric Meix-Llop

July 2012 


\title{
Do Fiscal and Political Decentralization Raise Students' Performance? A Cross-Country Analysis
}

\author{
Luis Diaz-Serrano \\ CREIP, Universitat Rovira i Virgili \\ and IZA \\ Enric Meix-Llop \\ CREIP, Universitat Rovira i Virgili
}

Discussion Paper No. 6722

July 2012

IZA

P.O. Box 7240

53072 Bonn

Germany

Phone: +49-228-3894-0

Fax: +49-228-3894-180

E-mail: iza@iza.org

Any opinions expressed here are those of the author(s) and not those of IZA. Research published in this series may include views on policy, but the institute itself takes no institutional policy positions.

The Institute for the Study of Labor (IZA) in Bonn is a local and virtual international research center and a place of communication between science, politics and business. IZA is an independent nonprofit organization supported by Deutsche Post Foundation. The center is associated with the University of Bonn and offers a stimulating research environment through its international network, workshops and conferences, data service, project support, research visits and doctoral program. IZA engages in (i) original and internationally competitive research in all fields of labor economics, (ii) development of policy concepts, and (iii) dissemination of research results and concepts to the interested public.

IZA Discussion Papers often represent preliminary work and are circulated to encourage discussion. Citation of such a paper should account for its provisional character. A revised version may be available directly from the author. 


\section{ABSTRACT}

\section{Do Fiscal and Political Decentralization Raise Students' Performance? A Cross-Country Analysis}

The low quality of education is a persistent problem in many developed countries. Parallel to in the last decades exists a tendency towards decentralization in many developed and developing countries. Using micro data from the Programme for International Student Assessment (PISA) referred to 22 countries, we test whether there exists an impact of fiscal and political decentralization on student performance in the areas of mathematics, reading skills and science. We observe that fiscal decentralization exerts an unequivocal positive effect on students' outcomes in all areas, while the effect of political decentralization is more ambiguous. On the one hand, the capacity of the subnational governments to rule on its region has a positive effect on students' performance in mathematics. On the other hand, the capacity to influence the country as a whole has a negative impact on mathematics achievement. As a general result, we observe that students' performance in Mathematics is more sensible to these exogenous variations than in Sciences and reading skills.

JEL Classification: $\quad \mathrm{H} 11, \mathrm{H} 77, \mathrm{I} 21$

Keywords: school outcomes, PISA, fiscal decentralization, political decentralization

Corresponding author:

Luis Diaz-Serrano

CREIP, Universitat Rovira i Virgili

Departament d'Economia

Av. de la Universitat 1

43204 Reus

Spain

E-mail: luis.diaz@urv.cat

\footnotetext{
* We acknowledge the financial support from the Spanish Ministry of Economy and Competitiveness (grant \#ECO2010-20829).
} 


\section{1 - Introduction}

The low quality of education is a persistent problem in many developed countries. It is common to see many of the most developed countries in not very favorable positions with the publication of various international tests that measure academic outcomes in compulsory education. That's why many of these countries have increased their efforts to try to improve the quality of their educational system. Indeed, this has been one of the priorities for the EU, as it was included in the Lisbon Strategy. ${ }^{1}$ Parallel to this situation in the last decades exists also a tendency towards decentralization in many developed and developing countries. The implications of increasing the quality of education raise the importance of the issue we deal with, that is the potential existence of a link between academic achievement and decentralization.

In public economics, the relationship between the provision of universal public services and decentralization is a recurring theme. However, one of the main problems in this analysis is that it is very difficult to measure the quality of and the efficiency in the provision of these services. We claim that this link between the efficient provision of public services and decentralization should receive more attention. We think that the connection of efficiency and equity in public services with decentralization should be at the core of the debate. The public services that should be the focus are education, health, and social protection for constituting these the three pillars of the welfare state, and we should expect these public services to be affected by decentralization processes. After all, the decentralization theorem (Oates, 1972, 1999) is about to deliver services closer to the people because of informational advantages of local governments about economic

\footnotetext{
${ }^{1}$ Since March 2000, the EU formulated its policies in line with the ambitious objectives of the so-called Lisbon Strategy, which sets a framework for action until 2010. Lisbon aims specifically for economic as well as social and environmental renewal. Improving students' performance in compulsory education in the EU was one of the priorities in the agenda.
} 
or social characteristics of regions. In the case of education, which is the focus of this paper, fiscal and political decentralization should promote a more efficient provision of this public good that would have to be translated into better students' performance. We think that at last students' grades is a good indicator of efficiency in the provision of public education.

Most studies devoted to analyze the effect of decentralization do it on economic ground such as economic growth, income inequality, and redistribution of wealth. However, these studies lose sight of that the main objective of decentralization is not economic growth or the redistribution of income, but better provision of public services to citizens. Recently, some studies are beginning to study the role of decentralization on variables involving happiness/satisfaction or the voters' perception of institutions. We find these studies are closer to the focus on what the analysis on the effects of decentralization should be. Our study seeks to be framed within this group of works, which try to determine the direct effect of decentralization on basic services, as in our case the education. ${ }^{2}$ Despite the relevance of this topic, the literature is virtually nonexistent.

The aim of this paper is to determine the role played by fiscal and political decentralization on academic performance (using academic results as a measure of efficiency of public education). With this goal, academic results will be used on areas as math, science or reading skills for more than 400,000 students from 22 countries belonging to all PISA studies available to date (2000, 2003, 2006 and 2009). This study is the first to use micro data on analyzing the role of the decentralization in education.

\footnotetext{
${ }^{2}$ Falch and Fischer (2010), and Diaz-Serrano and Rodriguez-Pose (2012) are two exceptions. This work will be discussed in more detail in the next section.
} 
We have to mention that our measures of fiscal and political decentralization are not specific of education. However, we should expect that a more decentralized country in the broader sense, will be also more decentralized in that regarding education. ${ }^{3}$. Our results are similar to the ones obtained in Diaz-Serrano and Rodríguez-Pose (2012) and suggest that the effect of fiscal decentralization is unequivocally positive, while the effect of political decentralization is more ambiguous. The authority of subnational governments over their own citizens reports a positive impact. By contrast, the capacity of subnational governments to influence the country as a whole exerts a negative impact.

With the objectives described above, the paper is structured as follows: Section 2, provides the conceptual framework of the study. Section 3 reviews the literature related to decentralization and education. In the section 4 are described the empirical methods used for analysis. Section 5 discusses the results. And finally section 6 contains the conclusions.

\section{2 - Conceptual framework}

The use of the word decentralization has become increasingly common in both economic and political language, although there is no a clear definition for execution. In both, public and private sector the word decentralization implies a change of authority in favor of lower levels of government hierarchy. One of the first authors to study the decentralization was Oates (1972) who establishes that decentralization bringing decisions closer to the population improves social welfare by reducing information asymmetry allowing for a better adjustment between local supply and heterogeneous

\footnotetext{
${ }^{3}$ We find this might be a potential limitation of our analysis. However, as far as we are aware education specific decentralization measures are generally not available.
} 
local demand. Thus, a decentralized fiscal system is expected to know and use public spending tight to the preferences of the population, obtaining the corresponding benefits to society in terms of efficiency gains. Tax revenues by the subnational governments provides incentives for good functioning of the decentralized system because, when part of local expenditures are financed with their own tax revenues, local authorities become directly accountable to the voters of the items where these taxes have been spent. Voters should be capable of evaluating correctly the performance of local governments and to give its verdict through the ballot box.

On the other hand, it is also possible that the different subnational governments compete to establish better baskets of goods and services in order to maintain their tax bases or attract taxpayers from other regions starting an expenditure competence. Similarly, it may occur that decentralization improves public service provision when local communities do not have the capacity to impose their views or local elites monopolize public resources on their own preferences (Bardhan and Mookherjee, 2005). For example, if these elites do not use the public health or educational system, they will push the government to destine the spending to other items. Smith (1985) shows that with decentralization of public services provision may not be efficient if subnational governments are less technically capable than the national governments to properly distribute public goods. Rondinelli et al (1984) identifies the problem of using decentralization in order to serve political objectives. In this way, the decentralization process is not evaluated by improvements in efficiency but also by how good or bad it satisfies the policy objectives. With this premise, it is common for central and subnational governments to have some tolerance when decentralization reforms 
translates into inefficient processes if the policy objective is met and the quality of public services does not decrease so as society expresses its rejection.

In the educational field, the need for decentralization comes from the new global economic conditions, McGinn and Welsh (1999). The discussion on the efficiency of a decentralized education system has been preceded by the adoption of market policies by most countries in both developed and developing countries. The increase of the universality of education has resulted in an increase on number of students enrolled in schools, therefore, spending on education has also been increased. In this scenario, many governments face great budget in educational matters that do not always translate into good results, this may involve an increase in the demand for skills on the part of governments.

Some reasons why governments decide to initiate decentralization processes around education are seeking improvements in efficiency, improvements in financing and redistribute power to of decision making bodies with better knowledge of educational needs. The efficiency goal is argued on the basis that a centralized system is often characterized by having a high bureaucratic burden thus incurring losses of resources and time. By decentralizing decisions, they are accelerated and at the same time, better information is available to run. The efficient allocation of resources by subnational governments allows to adjust better of the allocations in education as opposed to large national budgets that are not always allocated efficiently. On the other hand, the redistribution of decision-making is seen as a way to include the less weighted groups giving better facilities in attending their needs. The undesirable situations of the decentralization process may succeed if the resources are captured by local elites to be 
used in their favor or the inability (due to lack of sufficient material resources, intellectual or information) of the subnational government to run efficient policies. We think that students' outcomes (e.g. grades) are the best way of measuring efficiency in the education system.

Currently, most educational systems are based on the distribution of responsibilities across different levels of government. It is common that the central government set minimum requirements on the activities of subnational governments, which implies that are held accountable to central government.

\section{3 - Literature review}

\section{1- Decentralization}

Both from an empirically and theoretically view, the majority of studies relate the decentralization with the economic growth and results are not unambiguous. Another common feature of this literature is that only considers the impact of fiscal decentralization, while political decentralization is ignored. For instance, Davoodi and Zou (1998) in a study for 46 countries, and Rodríguez-Pose and Ezcurra (2010) in a study for 21 OECD countries find empirical evidence that the relationship between fiscal decentralization and economic growth is negative. Rodríguez-Pose and Ezcurra (2010) disaggregate the expenditure and find that the portion on education maintains the negative relationship with economic growth. This negative relation increases as countries intensify their process of fiscal decentralization. In contrast, Iimi (2005) observes a positive relationship between decentralization and growth in GDP per capita. In an empirical study for Spain, Carrion-i-Silvestre et al. (2007) report ambiguous 
effects of fiscal decentralization depending on whether they consider aggregated (negative) or regional (positive) level.

Another important topic of discussion is the role of decentralization as a depressor of poverty and inequality. In this vein, the World Bank included it as part of its poverty reduction program contained in the Development Committee (2006). Under tax competition, the richer regions may be more attractive to mobile factors to the fact that they offer better human capital or better infrastructure, under this premise and as Prud'homme (1995), this regions will become richer and the poor poorer. On the other hand, Ezcurra and Pascual (2008), Lessman (2009) and Qian and Weingast (1997) find that decentralization exerts a positive impact on the reduction of regional inequality. Thus less developed regions may offer attractive investment conditions such as more flexible labor markets, lower wages or lower tax rates. These investments could lead to improve the process of regional convergence. To Sepulveda and Martinez-Vazquez (2010), results vary depending on the level of total public expenditure, where fiscal decentralization could be a good way to reduce poverty if this represents a third or less of total spending. For higher levels, decentralization leads to an increase in levels of poverty.

Recently, there is a growing interest in studying the social dimension of decentralization. Thus, the literature linking decentralization and subjective well-being (SWB) seems to be taking off. ${ }^{4}$ The few existing empirical studies found that fiscal decentralization is important for subjective well-being (Frey and Stutzer, 2000; Bjørnskov et al., 2008, Diaz-Serrano and Rodríguez-Pose, 2012). The latter authors

\footnotetext{
${ }^{4}$ In the literature devoted to study the determinants of subjective well-being (SWB), the terms SWB, happiness and life satisfaction are often interchangeable.
} 
were also the firsts to study the effect of political decentralization, and observe that the effect on SWB is also positive. However, we think that focusing on the implications of decentralization for overall economic growth and territorial disparities, poverty, interpersonal inequality, social capital or SWB could be somewhat missing the point. While these factors may certainly be an indirect consequence of decentralization, the original aim of decentralization is fundamentally to improve the delivery of public goods and services to individuals by the creation of more legitimate tiers of government, closer to the people and, therefore, more responsive to their needs and wants. Decentralization is thus first and foremost about improving the delivery of public policies and, consequently, the level of satisfaction of the population with government and political institutions. At these regard, Diaz-Serrano and RodriguezPose (2012) are also the first to study the effect of decentralization on the perception of institutions by citizens (government, economy and democracy), while in Diaz-Serrano and Rodríguez-Pose (2011) the link between decentralization and satisfaction with health and educational system is also analyzed. These authors observed that fiscal and some forms of political decentralization have a positive and significant effect on the subjective well-being of citizens. On the other hand, fiscal decentralization has a different effect on the perception of institutions depending on whether we consider revenues or expenditure. In the same way, political decentralization also varies his effect on the level of satisfaction with institutions depending on whether the capacity of local governments to influence national politics or to exert authority over their own citizens. These results coincide with the ones we get here. From our point of view, the analysis we propose here is still better targeted on the problem, since we focus on the effect of decentralization on the, namely, efficiency of the education system through its effect on students' outcomes. 


\section{2- Students' performance}

The literature regarding the determinants of academic achievement can be disaggregated into three main groups: family and student background, school characteristics and institutional factors.

In terms of family and student background literature agrees on the importance of these factors in determining student performance. For example, having books at home is seen as a good indicator of social, educational and economic background of the student and therefore is presumed that this is causally related to student performance (Hanusek and Woessmann, 2011). The strong link between student achievement and socio-economic background is showed in cross-country studies at student level (Woessmann, 2003b) and country level (Lee and Barro, 2001)

Regarding effect of the school characteristics on school outcomes, the most studied issue are the inputs at it's disposal (Hanushek, 2006). If we consider the expenditures per student for schools, we see that there is no positive relationship between this factor and student achievement for both country-level analysis (Lee and Barro, 2001) and student level (Fuchs and Woessmann, 2007). This result might be due to what Hanusek (1997) called "productivity collapse in schools". In reference to other aspects related to the characteristics of the school, Lee and Barro (2001) find positive impact on a lesser number of students per class and the performance of these. The shortage of material and the intensive use of computers is presented as a factor that exerts a negative effect on student performance (Fuchs and Woessmann, 2004). As regards the scope of teachers, the educational level of those is presented as a factor that positively affects student performance as well as their wage level (Lee and Barro, 2001). 
The impact of the nature of school (public or private) has been extensively analyzed. Private schools are positively related to a better academic performance than the public ones (Woessmann et al, 2009). Another frequently discussed aspect is the level of autonomy of schools. Gunnarsoon, et al (2004) analyzed data from 10 primary schools in Latin America countries to estimate the impact of school autonomy and community participation in decision-making power of the schools (as proxies for the level of decentralization) on academic performance. They conclude that the effect is positive. Regarding the effect of institutional characteristics on academic achievement the literature is quite scarce. These institutional or constitutional features are not specific to the school but the education system. For example, (Bishop, 1997 and Bishop, 2006), show a positive impact on student achievement by the introduction of external curriculum tests.

\section{3- Decentralization and educational outcomes}

Although decentralization should be expected to be important for educational outcomes, the link between decentralization and education is undoubtedly under researched. Galiani et al (2008) study the impact of decentralization on the quality of education in Argentina. They find that decentralization has a positive impact on student academic performance. But also notes that the benefits of political decentralization do not reach students with less resources; therefore, their distribution is uneven. In the same line as the previous author, Barankay and Lockwood (2006) find that decentralization of expenditure in Switzerland allows reaching higher levels of academic achievement. Falch and Fischer (2010), using a panel of international student achievement for 23 OECD countries find that government expenditure decentralization has a positive effect on student performance. Behrman et al (2002) shows that there is little evidence that 
decentralization improves academic outcomes in developing countries. However, they claim that this result could be due to the lack of suitable data. Gunnarsoon, et al (2004) analyzed data from 10 primary schools in Latin American countries to estimate the impact of school autonomy and community participation in decision-making power of the schools (as proxies for the level of decentralization) on academic performance. They conclude that the effect is positive. Merrouche (2007), in an analysis for the Spanish case, argued that there was no improvement in human capital with the introduction of decentralization in education spending during the 80 's. In contrast, Salinas and SoléOllé (2009) found that this relationship is positive. Akai et al (2007) reached the same conclusion for high school students. Clements (1999) also studied the effect fiscal decentralization on academic performance in Portugal. He concluded that the worsening or not of improving academic performance may be evident due to inefficient spending on education.

\section{4 - Empirical framework and data}

\section{1 - Empirical model}

Models on the determinants of academic achievement are generally represented by an Educational Production Function (hereafter, EPF). This function is used as a way to understand the production processes by estimating the effects of various inputs on academic performance. Generally, this inputs includes information regarding student's background (individual and family characteristics) and school characteristics. The usual EPF can be represented by the following linear relationship:

$$
A_{i s}=\alpha+\beta X_{i s}+\gamma Z_{s}+\varepsilon_{i s}
$$


Where $A_{i s}$ is the academic achievement for student $i$, studying in school $s, X_{i s}$ contain the variables that characterize the student, $Z_{s}$ is a set of school characteristics, which are equal for all students attending the same school, $\varepsilon_{i s}$ is a random error term, and $\alpha, \beta, \gamma$ are the set of parameters to be estimated. Since our dataset consists in a pool of crosssections regarding different countries and periods, we expand the EPF expressed in equation (1) as follows:

$$
A_{i s c t}=\alpha+\beta X_{i s c t}+\gamma Z_{s c t}+\mu Y_{c t}+\lambda_{c}+\delta_{t}+\varepsilon_{i s t c}
$$

where and $Y_{c t}$ is a set of country characteristics including our variables of interest, i.e. political and fiscal decentralization,. $\delta_{t}$ are time effects and $\lambda_{c}$ are unobserved specific country effects. Time effects are included as dummy variables and are considered in order to control for any unobserved temporary shock that can alter the response variable and are not picked up by any of the other variable. On the other hand, $\lambda_{c}$ are considered in order to control for country unobserved heterogeneity. Furthermore, the inclusion of $\lambda_{c}$ is also necessary in order to identify the effects of the country variables of, among which we include decentralization indexes.

The estimation method selected to estimate equation (2) is the pooled linear model, where the temporary effects $\delta_{t}$ are introduced as dummy variables for each year. In order to control for cross-country unobserved heterogeneity the country-specific effects $\lambda_{c}$ can be considered as fixed or random-effects. If unobserved heterogeneity across the countries (each country has its own specific characteristics that might influence the outcomes) is correlated with the covariates, then random-effects estimator is 
inconsistent, since this model imposes as estimation restriction that this correlation is zero. Therefore, we choose the fixed- effects model. Since, the time dimension introduced in our model allows for variation throughout time of our country variables, as in panel data models we deal with country fixed-effects using the mean-differencing transformation. This method consists in differencing, for all variables in the model, each individual observation and the average of the country as follows:

$$
\left(A_{i s c t}-\overline{A_{c}}\right)=\left(X_{i s c t}-\overline{X_{c}}\right) \beta+\left(Z_{s c t}-\overline{Z_{c}}\right) \gamma+\left(Y_{c t}-\overline{Y_{c}}\right) \mu+\left(\varepsilon_{i s c t}-\overline{\varepsilon_{c}}\right)
$$

In equation (3), the within estimator at country level provides a consistent estimate of the fixed-effects model, at the time that allows to remove the country time-invariant specific component $\lambda_{c}$.

In order to carry out the estimation of equation (1), PISA recommends the use of balanced repeated replication (BRR) method, which provides statistically consistent estimator of the variance. For our empirical analysis we used the STATA module designed by Kevin MacDonald allowing us to estimate with multiple dependent variables (five test scores per student and subject, referred above as plausible values) by calculating the statistics for each dependent variable and then their average. In our case, we use this method to estimate equation (3).

\section{2 - Data}

The data used in this study are part of the Program for International Student Assessment (PISA). The PISA report is a international standardized study that provides academic results in the areas of math, science and reading. The study also collects information 
regarding the student and the family environment. There are four available waves conducted in a total of 43 countries in 2000, 41 countries in 2003, 57 countries in 2006 and 65 countries in the last edition of 2009.

Decentralization data is divided into political and fiscal decentralization variables. They come from two different sources. Political decentralization indexes are taken from Hooghe et al. (2008) Regional Authority Index (RAI) covering 42 countries for the period 1950-2006. The RAI is measured along eight dimensions, blending different areas of decentralization. On the other hand, fiscal decentralization data consist of yearly indicators calculated as the ratio between subnational and national expenditures or revenues covering the period 1972-2005. The source of these variables is the Government Finance Statistics of the International Monetary Fund.

In order to test the impact of decentralization on academic achievement we match the PISA database with the decentralization data. All students surveyed in PISA data and residing in the same country are assigned the same value of corresponding decentralization indicator. In this matching, we have not only taken into consideration the spatial but also the appropriate time horizon. We assign to each country the average of the last ten years of the decentralization index prior to each PISA wave. Since the decentralization indexes are comprised between 1965 and 2006, for the PISA wave of 2009 we assign the same values of the decentralization indexes as in 2006 .

Since our decentralization data covers a more reduced number of countries than those in the PISA database, our final sample is composed of 22 countries. In Table 1 (see Appendix) we report sample size by country and year. 


\subsection{1 - Dependent variables}

In PISA database, students' scores on math, science and reading skills are presented in the form of five plausible values ${ }^{5}$ for each student and subject. The plausible values (PV) were used for the first time in the National Assessment of Educational Progress (NAEP) in 1983-1984. The PV are also used in TIMSS and PISA evaluations of education. They were developed to obtain consistent estimates of population characteristics in assessing situations where there are not enough resources to make an accurate estimate of their abilities.

The statistics concerning the aggregated academic results by country are shown in Table 2 (see Appendix). This summary statistics is not referred to all the countries participating in PISA, but to the 22 countries in our final sample. We can see that the best five performing countries in mathematics are Finland, Holland, Switzerland, New Zealand and Belgium. Regarding reading skills, Finland repeats again as the first in the ranking followed by New Zealand, Holland, Ireland and Australia. Finally, the countries with the highest average score in science are Finland, Netherlands, Czech Republic, New Zealand and Australia. It should be noted that Finland is maintained in the first position of the ranking in the three subjects, while the Netherlands and New Zealand are always among the top five countries. The worst results are obtained by Greece who appears on the last position in the three achievements. Portugal's performance is ranked the second worst in the three subjects tested. Regarding the third worst place, is held by the United States in mathematics, by Spain in reading skills and by Denmark in science.

\subsection{2 - Independent variables}

\footnotetext{
${ }^{5}$ The plausible values are students imputed values that are similar to the individual test scores and have approximately the same distribution as the measured latent feature.
} 
In order to determine the effect of decentralization on academic achievement we include a number of covariates consisting of student characteristics, characteristics of the school and specific country variables to which the student belongs including our key variables of political and fiscal decentralization.

Student characteristics comprise a set of individual's and the family characteristics. These are gender, age, birthplace of the student and their parents, the number of books they have at home, and the cultural level of the father and mother ${ }^{6}$. This type of variables that define the individual and their background represent the most important factors in addition to the unobserved innate ability to explain the performance of students (Woessmann, 2000).

The variables used to characterize the school the student belongs includes the type of urban area in which the school is located (it can take 5 values based on its size), the type of school (public school, private school independent of government and government-dependent private school) and the ratio between the number of students and teachers.

In order to identify the effect of the country decentralization indexes on students' outcomes, in addition to estimate a country fixed-effects models, we also include a number of country-level variables. These variables are the GDP per capita at constant 2000 prices, ${ }^{7}$ the annual expenditure on educational institutions per student, secondary

\footnotetext{
${ }^{6}$ This level is measured by the International Standard Classification of Education (ISCED), which refers to the standardized classification of the different educational levels established by UNESCO, which allows comparison between countries.

${ }^{7}$ Word Development indicators: World Bank.
} 
education teacher salaries and total education expenditure as a percentage of the GDP, ${ }^{8}$ the unemployment youth rate $^{9}$ and an index of corruption perception in the public sector. $^{10}$

Our key independent variables are the fiscal and political decentralization indicators. Political decentralization variables come from the Regional Authority Index (RAI), which was constructed by Hooghe et al. (2008). We use two aggregated indexes (Selfrule and Shared-rule) covering two dimensions of political decentralization for 42 countries covering the period 1950-2006. ${ }^{11}$ Self-rule is a measure of the authority exercised by subnational governments over their own citizens. Shared-rule refers to the capacity of subnational governments or its representatives to influence the country as a whole.

Fiscal decentralization indexes are from the Government Finance Statistics of the International Monetary Fund for the period 1972-2005. These are the ratio between subnational and total expenditures and revenues. This dataset provides separate indexes for current and capital expenditure. Regarding the revenue side, we distinguish between total revenues and revenues coming from taxes.

In Table 6 (see Appendix) we show the ranking of countries according to their level of political and fiscal decentralization. For fiscal decentralization, the ranking is constructed by averaging the five indexes used in the analysis (total expenditure, capital expenditure, current expenditures, total revenues and tax revenues). The three most

\footnotetext{
${ }^{8}$ Education at a Glance: OECD Indicators.

${ }^{9}$ Labour Force Statistics: OECD.

${ }^{10}$ Transparency International Corruption Perceptions Index.

${ }^{11}$ The RAI was validated in Schakel (2008).
} 
fiscally decentralized countries are Switzerland, Germany and Denmark, while Portugal, Iceland and the UK are at the bottom of the ranking. Regarding political decentralization,, the top of the ranking is composed by Germany, Belgium, United States, while Czech Republic and Portugal are at the bottom.

It is important to distinguish between political and fiscal decentralization, since not all the most fiscally decentralized countries are the most politically decentralized, and viceversa (see Figure 1). For instance, Germany, Spain, Belgium, Switzerland and the United States combine high levels of both political and fiscal decentralization. However, countries as Sweden or Denmark are characterized by high levels of fiscal decentralization combined with low levels of political decentralization, while in the UK and Hungary it is the other way around.

\section{5 - Econometric results}

Table 7 (see Appendix) reports the results obtained in the estimation of equation (2) for the three outcome variables: math achievement, read achievement and science achievement.

The top part of the table comprises the individual characteristics. These variables are statistically significant for all academic outcomes, which coincides with the previous empirical evidence using the PISA data. With the exception of gender, estimated coefficients associated to individual characteristics report the same sign for the three outcome variables. Women tend to exhibit worse results than men in math and science but better in reading skills. Regarding the student's household environment, we observe that estimated coefficients also behave according to expectations. The number of books 
at home and the educational attainment of the parents exert a positive impact on academic performance. On the contrary, the foreign-born status of the student and the parents affects student's performance negatively. School characteristics have also turned out to be statistically significant in determining our three outcome variables. Students' scores are higher in private schools than in public or semi-public schools. Student's performance also improves as city size and the ratio between teachers and students increases.

As one could expect, country specific variables have also turned out to be statisitically significant. We observe that in countries with larger education expenditure per student, larger GDP per capita and larger expenditure in education as a percentage of GDP, students performance is poorer. This holds for the three subjects of study and reinforces the idea mentioned in the introduction that quality of education in richer countries is a persistent problem. On the contrary, the level of secondary education teachers salaries exerts a positive impact on school outcomes. The unemployment youth rate (between 15 and 24) has a positive effect on performance. This result indicates that exists incentives among students to improve school performance in a context of high youth unemployment in order to become more competitive in the labor market. Finally, we observe that the corruption index has a positive and significant effect, wich again is in line with a poorer performance in more developed countries.

Now we focus on the results coming our variables of interest, i.e. fiscal and political decentralization. We observe that while fiscal decentralization exerts an unambiguous positive effect on all outcomes (mathematics, science and reading skills). Results regarding political decentralization are ambiguous. This results fit with the findings in 
Diaz-Serrano and Rodríguez-Pose (2012) regarding the effect of decentralization on subjective well-being and the perception of institutions.

Regarding the impact of fiscal decentralization, we observe that subnational current expenditure, which mainly regards to human resources, exerts a statistically significant positive effect in all subjects of study. However, subnational capital expenditure reports this positive effect only for math scores, and being non statistically significant for sciences and reading skills. Analogously, subnational revenue also exerts a significant positive effect on all students' outcomes. In contrast with the evidence regarding fiscal decentralization, the effect of political decentralization on student's performance is more limited and ambiguous. We observe that our indicators of political decentralization exert a statistically significant effect only for math scores. The effect of the capacity of subnational governments to rule over their own citizens (self-rule) is positive, while the capacity of subnational governments to influence the country as whole (shared-rule) exerts an negative impact. All these results taken together, i.e. significance and magnitude of the estimated marginal effects, suggests not only that decentralization matters for school outcomes, but students' performance is mathematics is more sensitive to more decentralized educational policies than other subjects as sciences or reading skills.

So far, the combination of the ambiguous and more limited effect of political decentralization with the unambiguous positive effect of fiscal decentralization is interesting. From these results it follows that for school outcomes it is more important the capacity of subnational governments to deliver than the capacity to decide on their own educational policies. 


\section{6 - Conclusions}

This paper has analyzed the impact of fiscal and political decentralization on students performance. With this aim, we resort to the four available waves of the PISA microdata regarding 22 countries for the years 2000, 2003, 2006 and 2009.

After controlling for a large number of individual, school and country characteristics our results indicate that decentralization matters for students' performance. For fiscal decentralization, estimated effects are positive in all outcomes for both expenditures and revenues. This result indicates that in countries where subnational governments have more capacity to manage their own budgets, from both the expenditure and revenue side, students perform better. This is because local governments are more efficient allocating their expenditures. On the contrary, the effect of political decentralization is only significant in math scores but ambiguous, i.e. positive for selfrule and negative for shared-rule. This result also supports the notion that local governments on gaining autonomy to articulate its own policies are able to run with greater efficiency. However, it is not so when the same local governments have the capacity to have an influence on national policies. . Another interesting result regards the fact as other studies has shown, math scores seems to be more sensitive to policy and budgetary changes that other subjects as science or reading skills. 


\section{References}

Akai, N., Sakata, M., Tanaka, R., (2007), Financial Decentralization and Educational Performance: Evidence form State-level Panel Data for the United States, Institute of Business and Economic Research, Conference Paper No. C07-011, University of California, Berkeley

Barankay, I., Lockwood, B., (2006), Decentralization and Productive Efficiency of Government: Evidence form Swiss Cantons, IZA Discussion Papers, No. 2477 Institute for the Study of Labour (IZA)

Bardhan, P., Mookherjee, D., (2005), Decentralizing antipoverty program delivery in developing countries. Journal of Public Economics 89 (4), 675-704.

Behrman, J. R., Deolalikar, A. B., Soon, L., (2002), Conceptual Issues in the Role of Education Decentralization in Promoting Effective Schooling in Asian Developing Countries, ERD Working Paper Series, No. 22 Asian Development Bank

Bishop, J. H., (1997), The effect of national standards and curriculum-based examinations on academic achievement. American Economic Review 87, no. 2: 260-264

Bishop, J. H., (2006), Drinking from the fountain of knowledge: Student incentive to study and learn. Externalities, information problems and peer pressure. In Handbook of Economics of Education, edited by Eric A. Hanushek and Finis Welch. Amsterdam: North Holland: 909-944 
Borland, M. V., Howsen, R. M., Trawick, M. W., An Investigation of the Effect of Class Size on Student Academic Achievement, Education Economics, 13 73-83

Bjørnskov, C., Drehe, A. and Fischer, J.A.V. (2008) On decentralization and life satisfaction. Economics Letters 99 (1): 147-151.

Carrion-i-Silvestre, J. Ll., Espasa, M. and Mora, T. (2007): "Fiscal decentralization and economic growth in Spain”, Public Finance Review, 36, 2, 194-218.

Clements, B., (1999), The Efficiency of Education Expenditure in Portugal, IMF Working Paper, No. 179 International Monetary Found

Davoodi, H., Zou, H. 1998. Fiscal Decentralization and Economic Growth: a CrossCountry Study, Journal of Urban Economics, 43 244-257.

Development Committee (2006). Strengthening Bank Group Engagement on Governance and Anti- corruption. Washington, D.C.: Joint Ministerial Committee of the Boards of Governors of the World Bank and the International Monetary Fund on the Transfer of Real Resources to Developing Countries.

Diaz-Serrano, L., Rodríguez-Pose, A., (2011) Decentralization, Happiness and the Perception of Institutions, IZA Discussion Papers, No. 5647 Institute for the Study of Labour (IZA) 
Diaz-Serrano, L., Rodríguez-Pose, A., (2012), Decentralization, Subjective Well-Being and the Perception of institutions, Kyklos, forthcoming.

Entorf, H., Minoiu, N., (2005) What a difference immigration policy makes: A comparison of PISA scores in Europe and traditional countries of immigration. German Economic Review 6, no. 3: 355-376

Ezcurra, R., Pascual, P., (2008), Fiscal Decentralization and Regional Disparities: Evidence from Several European Union Countries, Environment and Planning, 40 $1185-1201$

Falch, T., Fischer, J., (2010), Public Sector Decentralization and School Performance: International Evidence, Working Papers Chair for Economic Policy, No. 31 University of Hamburg

Frey, B.S. and Stutzer, A. (2000) Happiness, Economy and Institutions. The Economic Journal 110 (466): 918 - 938.

Fuchs, T., Woessmann, L., (2004), Computers and student learning: Bivariate and multivariate evidence on the availability and use of computers at home and at school. Brussels Economics Review 47, no. 3/4: 359-385.

Fuchs, T., Woessmann, L., (2007), What accounts for international differences in student performance? A re-examination using PISA data. Empirical Economics 32, no. 2-3: 433-462 
Galiani, S., Gertler, P., Schargrodsky, E., (2008), School decentralization:Helping the good get better, but leaving the poor behind, Journal of Public Economics, 92 21062120

Gunnarsson, V., Orazem P., Sanchez M., Verdisco A., (2004),Does School Decentralization Raise Student Outcomes? Theory and Evidence on the Roles of School Autonomy and Community Participation. Working Paper 04005, Iowa Stata University Depart of Economics.

Hanushek E. A., (1997), The productivity collapse in schools. Developments in School finance, 1996, edited by William J. Fowler, Jr. Washington, DC: National Centre for Education Statistics: 185-195.

Hanushek E. A., (2006), School resources. Handbook of the Economics of Education, edited by Eric A. Hanushek and Finis Welch. Amsterdam: North Holland: 865-908.

Hanushek E. A., Woessmann L., (2011), Chapter 2: The Economics of International Differences in Educational Achievement in Handbook of the Economics of Education, Elsevier, 2011, Volume 3, Pages 89-200

Harris, D.N., Sass, T.R., (2011), Teacher Training, Teacher Quality and Student Achievement, Journal of Public Economics 95 798-812 
Hooghe, L., Marks, G., Schakel, A.H., (2008) Regional Authority in 42 Democracies, 1950-2006. A Measure of Five Hypotheses. Regional and Federal Studies 18 (2-3): $111-302$

Iimi, A. (2005), Decentralization and Economic Growth Revisited: an Empirical Note, Journal of Urban Economics, 57 449-461

Kirjavainen, T., Häkkinen Iida, Uusitalo, R., (2000), School Resources and Student Achievement Revisited: New Evidence Using Panel Data, VATT-Discussion Papers, Government Institute for Economic Research, Helsinki 2000

Klugman, J., (1997), Decentralization: A Survey from a Child Welfare Perspective, Economic and Social Policy Series, No. 61

Konstantopoulos, S., (2005), Trends of School Effects on Student Achievement: Evidence from NLS:72, HSB:82, and NELS:92, IZA Discussion Paperss, No. 1749

Lee, J., Barro R. J., (2001), Schooling quality in a cross-section of countries, Economica 68, no. $272: 465-488$.

Lessmann, C., (2009). Fiscal Decentralization and Regional Disparity: Evidence from Cross-Section and Panel Data, Environment and Planning 41(10), pages 2455-2473

McGinn, N., Welsh, T., (1999) Decentralization of Education: Why, When, What and How?, Fundamentals of educational planning UNESCO, IIEP, Paris. 
Merrouche, O., (2007), The Long Term Effect of Education Spending Decentralization on Human Capital in Spain, UCD Geary Institute Discussion Paper Series, No. 9 UCD Dublin

Metzler, J., Woessmann, L., (2010), The Impact of Teacher Subject Knowledge on Student Achievement: Evidence from Within-Teacher Within-Student Variation, CESifo, Working paper No. 3011

Oates, W. E., (1972) Fiscal Federalism, New York: Harcourt Brace Jovanovich.

Oates, W. E., (1999) An Essay on Fiscal Federalism, Journal of Economic Literature, vol. 37(3),1120-1149

Prud'homme, R., (1995), On the dangers of decentralization, Policy Research WP 1252, World Bank, Washington, DC

Qian Y., Weingast B., (1997), Federalism as a commitment to preserving market incentives, Journal of Economic Perspectives 11 83-92

Rodriguez-Pose, A., Ezcurra, R., (2010) Is Fiscal Decentralization Harmful for Economic Growth? Evidence from the OECD countries. Journal of Economic Geography, forthcoming 
Rondinelli, D.A. (1981), Government decentralization in comparative perspective: Theory and practice in developing countries, International Review of Administrative Sciences, $67133-145$.

Rondinelli, D., Nellis J., Cheema, G., (1984), Decentralization in Developing Countries World Bank Staff Working Papers 581 The World Bank Washington.

Salinas, P., Solé-Ollé, A., (2009), Evaluating the Effects of Decentralization on Educational Outcomes in Spain, Documents de Treball de l'IEB 2009/2010, Institut d'Economia de Barcelona

Schakel, A.H., (2008) Validation of the Regional Authority Index, Regional and Federal Studies 18 (2-3) 143-166

Sepulveda C F, Martinez-Vazquez J, (2011), The consequences of fiscal decentralization on poverty and income equality, Environment and Planning $C$ : Government and Policy 29(2) $321-343$

Smith, B. (1985), Decentralization: The territorial dimension of the state. George Allen \& Unwin, London.

Sprietma, M., (2010), The effect of relative age in the first grade of primary school on long-term scholastic results: International comparative evidence using PISA 2003, Education Economics 18, no. 1: 1-32. 
Todd, P. and K- Wolpin (2003), On the specification and estimation of the production function for cognitive achievement, The Economic Journal, Vol. 113(485).

von Davier M., Gonzalez E., Mislevy R., (2009) What are plausible values and why are they useful? IERI Monograph Series Issues and Methodologies in Large-Scale Assessments IER Institute. Educational Testing Service.

Winkler, D., (1989), Decentralization in Education: An Economic Perspective, Washington: World Bank. 143.Washington: World Bank.

Woessmann, L. (2003), Schooling resources, educational institutions and student performance: The international evidence, Working Pepers 983, Kiel Institute of World Economics.

Woessmann, L., Luedemann, E., Schuetz, G., West, M., (2009), School accountability, autonomy, and choice around the world, Cheltenham, UK: Edward Elgar

Wu, M., (2005) The Role of Plausible Values in Large Scale Surveys, Studies in Educational Evaluation 31 114-128 


\section{Annex}

Table 1: Observations by country and year

\begin{tabular}{lrrrr}
\hline & 2000 & \multicolumn{1}{c}{2003} & \multicolumn{1}{c}{2006} & \multicolumn{1}{c}{2009} \\
\hline Australia & 1.122 & 12.551 & 14.170 & 14.251 \\
Austria & 1.091 & 4.597 & 4.927 & 6.590 \\
Belgium & 1.563 & 8.796 & 8.857 & 8.501 \\
Czech Republic & 1.326 & 6.320 & 5.932 & 6.064 \\
Denmark & 957 & 4.218 & 4.532 & 5.924 \\
Finland & 1.085 & 5.796 & 4.714 & 5.810 \\
France & 1.044 & 4.300 & 4.716 & 4.298 \\
Germany & 1.157 & 4.660 & 4.891 & 4.979 \\
Greece & 1.040 & 4.627 & 4.873 & 4.969 \\
Hungary & 1.229 & 4.765 & 4.490 & 4.605 \\
Iceland & 743 & 3.350 & 3.789 & 3.646 \\
Ireland & 849 & 3.880 & 4.585 & 3.937 \\
Italy & 1.109 & 11.639 & 21.773 & 30.905 \\
Netherlands & 553 & 3.992 & 4.871 & 4.760 \\
New Zealand & 814 & 4.511 & 4.823 & 4.643 \\
Norway & 918 & 4.064 & 4.692 & 4.660 \\
Portugal & 1.030 & 4.608 & 5.109 & 6.298 \\
Spain & 1.362 & 10.791 & 19.604 & 25.887 \\
Sweeden & 976 & 4.624 & 4.443 & 4.567 \\
Switzerland & 1.385 & 8.420 & 12.192 & 11.812 \\
United Kingdom & 2.078 & 9.535 & 13.152 & 12.179 \\
United States & 843 & 5.454 & 5.611 & 5.233 \\
\hline & & & &
\end{tabular}

Table 2: Summary statistics for the results in mathematics, reading and science

\begin{tabular}{|c|c|c|c|c|c|c|c|c|c|}
\hline & \multicolumn{3}{|c|}{ Maths achievement } & \multicolumn{3}{|c|}{ Reading achievement } & \multicolumn{3}{|c|}{ Science achievement } \\
\hline & mean & s.d. & rank & mean & s.d. & rank & mean & s.d. & rank \\
\hline Australia & 515.72 & 90.16 & 7 & 513.54 & 95.61 & 5 & 522.30 & 99.13 & 5 \\
\hline Austria & 506.25 & 90.15 & 9 & 487.47 & 98.08 & 19 & 503.25 & 93.31 & 12 \\
\hline Belgium & 525.91 & 101.16 & 5 & 509.20 & 101.25 & 6 & 511.77 & 99.32 & 8 \\
\hline Czech Republic & 524.99 & 99.46 & 6 & 502.78 & 98.55 & 8 & 530.26 & 99.03 & 3 \\
\hline Denmark & 503.84 & 85.10 & 11 & 488.46 & 84.99 & 16 & 483.85 & 92.88 & 20 \\
\hline Finland & 542.51 & 77.38 & 1 & 540.25 & 79.35 & 1 & 550.30 & 83.78 & 1 \\
\hline France & 504.07 & 91.36 & 12 & 497.10 & 96.98 & 11 & 503.34 & 99.42 & 13 \\
\hline Germany & 506.74 & 96.07 & 10 & 495.83 & 101.83 & 14 & 512.67 & 99.65 & 7 \\
\hline Greece & 457.38 & 87.37 & 22 & 472.07 & 94.57 & 22 & 475.98 & 87.61 & 22 \\
\hline Hungary & 492.08 & 87.65 & 18 & 487.92 & 86.99 & 17 & 504.71 & 85.78 & 11 \\
\hline Iceland & 509.20 & 84.80 & 8 & 492.45 & 91.97 & 15 & 493.58 & 90.36 & 17 \\
\hline Ireland & 498.60 & 80.46 & 15 & 512.52 & 88.10 & 4 & 508.59 & 90.07 & 9 \\
\hline Italy & 485.01 & 89.07 & 19 & 488.27 & 94.76 & 18 & 496.23 & 92.42 & 16 \\
\hline Netherlands & 538.52 & 85.81 & 2 & 516.85 & 85.74 & 3 & 530.77 & 92.05 & 2 \\
\hline New Zealand & 524.44 & 91.92 & 4 & 523.27 & 100.22 & 2 & 530.05 & 101.67 & 4 \\
\hline Norway & 494.56 & 85.19 & 16 & 494.81 & 95.81 & 13 & 491.14 & 91.18 & 19 \\
\hline Portugal & 474.14 & 85.84 & 21 & 480.51 & 88.31 & 21 & 479.06 & 83.45 & 21 \\
\hline Spain & 494.84 & 86.28 & 17 & 484.19 & 85.35 & 20 & 495.92 & 86.31 & 15 \\
\hline Sweeden & 502.56 & 88.42 & 13 & 506.71 & 92.74 & 7 & 502.16 & 94.62 & 14 \\
\hline Switzerland & 526.30 & 91.24 & 3 & 494.83 & 87.75 & 10 & 506.57 & 93.28 & 10 \\
\hline United Kingdom & 500.88 & 86.08 & 14 & 500.68 & 93.96 & 9 & 515.00 & 98.44 & 6 \\
\hline United States & 480.71 & 87.63 & 20 & 495.52 & 94.61 & 12 & 492.66 & 96.92 & 18 \\
\hline
\end{tabular}


Table 3: Description of the variables of individual characteristics

\begin{tabular}{|c|c|}
\hline Variable & Description \\
\hline Female & Dummy that takes value 1 if the individual is female. \\
\hline Age & Age of the student \\
\hline Student born in foreign country & Dummy that takes value 1 if the student was not born in the country of performance of the test \\
\hline Mother born in foreign country & $\begin{array}{l}\text { Dummy that takes value } 1 \text { if the mother of the student was not born in the country of performance of } \\
\text { the test }\end{array}$ \\
\hline Father born in foreign & Dummy that takes value 1 if the father was not born in the country of performance of the test \\
\hline Books at home & $\begin{array}{l}\text { Number of books that the individual has at home. Can take the values none, } 1 \text { to } 10,11 \text { to } 50,51 \text { to } \\
100,101 \text { to } 250,251 \text { to } 500 \text { and more than } 500\end{array}$ \\
\hline Father isced qualification & $\begin{array}{l}\text { Father ISCED rating } \\
\text { 0: preschool } \\
\text { 1: primary } \\
\text { 2: low secondary education } \\
\text { 3: high secondary education } \\
\text { 4: postsecondary education } \\
\text { 5: low tertiary education, diplomas, degrees and postgraduate } \\
\text { 6: high tertiary education, doctoral and master certain, includes part of research }\end{array}$ \\
\hline Mother isced qualification & Mother ISCED rating \\
\hline
\end{tabular}

Table 4: Description of the variables of school characteristics

\begin{tabular}{|l|l|}
\hline Variable & \multicolumn{1}{|c|}{ Description } \\
\hline Location & $\begin{array}{l}\text { It takes the following values depending on where the school is located: } \\
\text { Village: less than } 3,000 \text { inhabitants } \\
\text { Small town: between } 3,000 \text { and } 15,000 \text { inhabitants } \\
\text { Town: between } 15,000 \text { and } 100,000 \\
\text { City: between } 100,000 \text { and } 1,000,000 \text { people } \\
\text { Large city: more than } 1,000,000 \text { inhabitants }\end{array}$ \\
\hline School type & $\begin{array}{l}\text { Can take the following values: } \\
\text { Public: if the school is owned by the government } \\
\text { Private: If the school is private and independent of government } \\
\text { Private government-dependent }\end{array}$ \\
\hline School size/teachers ratio & Ratio between number of students and teachers \\
\hline
\end{tabular}


Table 5: Description of the variables at the country level

\begin{tabular}{|l|l|}
\hline Variable & \multicolumn{1}{|c|}{ Description } \\
\hline GDP per capita constant prices 2000 & PIB per capita constant 2000 prices \\
\hline Expenditure per student & $\begin{array}{l}\text { Annual expenditure on educational institutions per student converted to dollars } \\
\text { using PPP. }\end{array}$ \\
\hline Teacher salary at primary education & Primary annual initial salary converted to dollars using PPP \\
\hline Teacher salary at low secondary education & Low secondary annual initial salary converted to dollars using PPP \\
\hline Teacher salary at upper secondary education & High secondary annual initial salary converted to dollars using PPP \\
\hline Total expenditure in education as \% of GDP & Public expenditure on educational institutions of primary and secondary schools \\
as a percentage of GDP
\end{tabular}


Table 6: Average rates of political and fiscal decentralization by country

\begin{tabular}{|c|c|c|c|c|c|c|}
\hline & \multicolumn{2}{|c|}{ Self Rule } & \multicolumn{2}{|c|}{ Shared Rule } & \multicolumn{2}{|c|}{$\begin{array}{l}\text { Subnational Fiscal } \\
\text { Decentralization }\end{array}$} \\
\hline & Score & Rank & Score & Rank & Score & Rank \\
\hline Australia & 12.9446 & 8 & 6.0334 & 4 & 0.4971 & 6 \\
\hline Austria & 12 & 9 & 6 & 5 & 0.4095 & 10 \\
\hline Belgium & 21.0046 & 1 & 7.6170 & 2 & 0.4656 & 7 \\
\hline Czech Republic & 3.3687 & 21 & 0 & 14 & & \\
\hline Denmark & 10.0794 & 10 & 0.1138 & 12 & 0.5160 & 3 \\
\hline Finland & 6.76762 & 18 & 0.0299 & 13 & 0.4289 & 9 \\
\hline France & 16 & 6 & 0 & 14 & 0.2931 & 15 \\
\hline Germany & 20.3375 & 2 & 9 & 1 & 0.5632 & 2 \\
\hline Greece & 9.25 & 14 & 0 & 14 & & \\
\hline Hungary & 9.5 & 13 & 0 & 14 & 0.2719 & 16 \\
\hline Iceland & 0 & 22 & 0 & 14 & 0.2636 & 18 \\
\hline Ireland & 5.6250 & 19 & 0 & 14 & 0.3498 & 14 \\
\hline Italy & 18.6883 & 4 & 1.4900 & 9 & 0.3561 & 13 \\
\hline Netherlands & 7.925 & 17 & 6.5 & 3 & 0.3790 & 12 \\
\hline New Zealand & 9 & 15 & 0 & 14 & & \\
\hline Norway & 10 & 11 & 0 & 14 & 0.3893 & 11 \\
\hline Portugal & 3.3830 & 20 & 0.1645 & 11 & 0.2097 & 19 \\
\hline Spain & 18.9156 & 3 & 3.0174 & 8 & 0.4512 & 8 \\
\hline Sweeden & 10 & 11 & 0 & 14 & 0.5072 & 5 \\
\hline Switzerland & 15 & 7 & 4.5 & 7 & 0.5692 & 1 \\
\hline United Kingdom & 8.1079 & 16 & 0.3110 & 10 & 0.2709 & 17 \\
\hline United States & 17.6987 & 5 & 5.4888 & 6 & 0.5151 & 4 \\
\hline
\end{tabular}




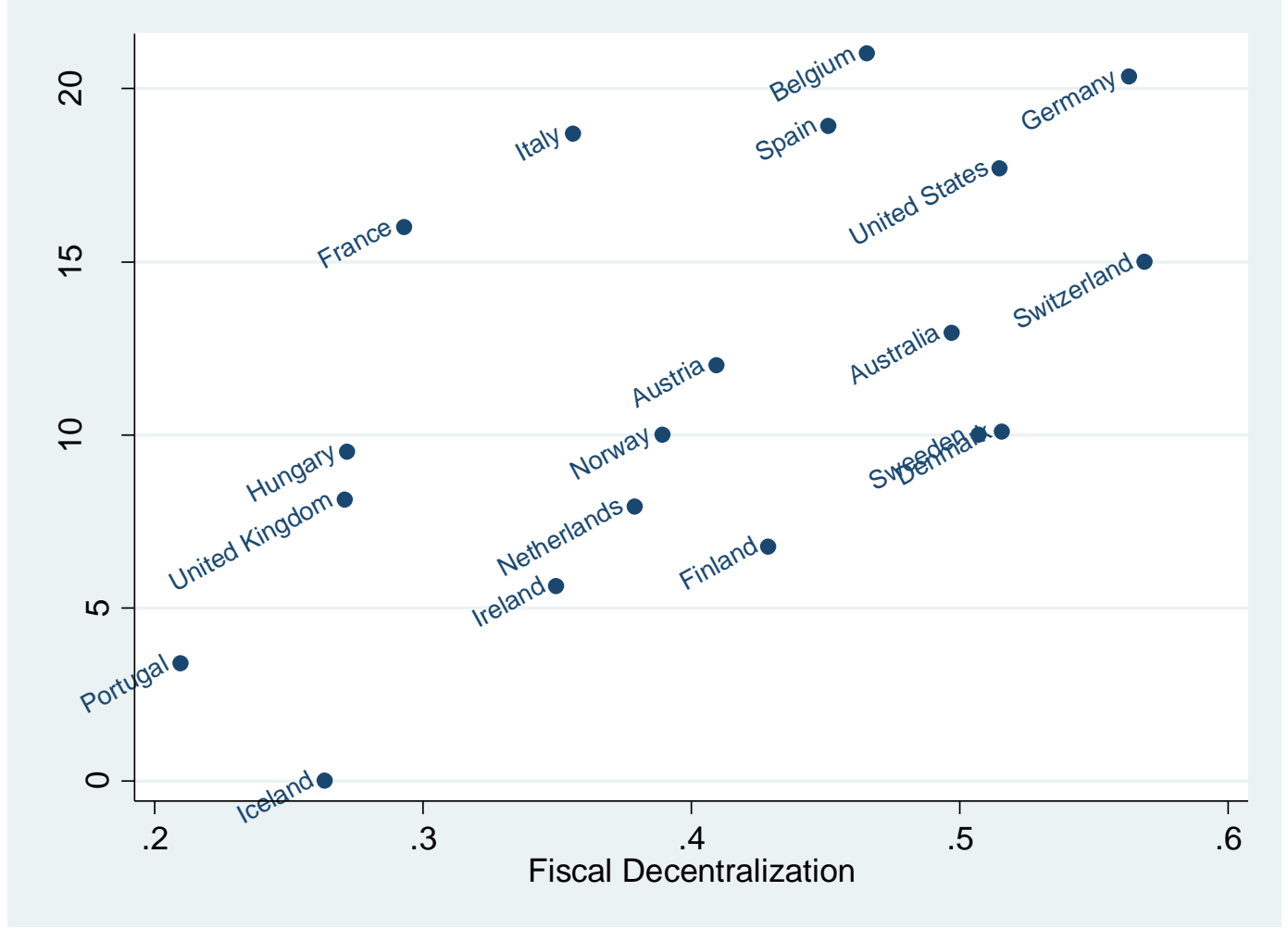

Figure 1: Relationship between Fiscal and Political decentralization 
Table 7: Estimation with fixed effects of equation (2). The fixed effects and standard errors are clustered at country level

\begin{tabular}{|c|c|c|c|c|c|c|}
\hline & \multicolumn{2}{|c|}{ Math achievement } & \multicolumn{2}{|c|}{ Reading achievement } & \multicolumn{2}{|c|}{ Science achievement } \\
\hline & Coefficient & t-stat & Coefficient & t-stat & Coefficient & t-stat \\
\hline \multirow{2}{*}{\multicolumn{7}{|c|}{ Individual characteristics }} \\
\hline & & & & & & \\
\hline Female & -0.0030 & $-9.93 * * *$ & 0.0664 & $22.02 * * *$ & -0.0102 & $-3.55^{* * *}$ \\
\hline Age & 0.0014 & $3.14 * * *$ & 0.0035 & $3.32 * * *$ & 0.0012 & 0.94 \\
\hline Student born in foreign country & -0.0331 & $-4.13 * * *$ & -0.0365 & $-4.17 * * *$ & -0.0258 & $-4.14^{* * * *}$ \\
\hline Mother born in foreign country & -0.0185 & $-3.43 * * *$ & -0.0246 & $-3.48 * * *$ & -0.0034 & $-2.82^{* * * *}$ \\
\hline Father born in foreign & -0.0428 & $-6.79 * * *$ & -0.0405 & $-5.85 * * *$ & -0.0223 & $-4.66^{* * *}$ \\
\hline \multicolumn{7}{|l|}{ Books at home (Base: None) } \\
\hline $1-10$ Books & 0.0477 & $9.12 * * *$ & 0.0685 & $11.72 * * *$ & 0.0559 & $10.55^{\text {**** }}$ \\
\hline $11-50$ Books & 0.1118 & $22.58 * * *$ & 0.1356 & $24.81 * * *$ & 0.1214 & $25.49^{* * *}$ \\
\hline $51-100$ Books & 0.1553 & $28.12 * * *$ & 0.1784 & $30.50 * * *$ & 0.1556 & $29.07 * * *$ \\
\hline $101-250$ Books & 0.1915 & $35.14 * * *$ & 0.2137 & $39.33^{* * * *}$ & 0.1871 & $33.61 * * *$ \\
\hline $251-500$ Books & 0.2099 & $31.81 * * *$ & 0.2296 & $34.46 * * *$ & 0.1946 & $30.48^{* * *}$ \\
\hline More than 500 & 0.2228 & $20.80^{* * * *}$ & 0.2433 & $22.31 * * *$ & 0.1942 & $17.62^{* * * *}$ \\
\hline Father isced qualification & 0.0096 & $11.05^{* * * *}$ & 0.0103 & $9.87 * * *$ & 0.0131 & $13.99^{* * * *}$ \\
\hline Mother isced qualification & 0.0086 & $8.93^{* * *}$ & 0.0107 & $9.43^{* * *}$ & 0.0103 & $10.66^{* * *}$ \\
\hline \multicolumn{7}{|l|}{ School characteristics } \\
\hline \multicolumn{7}{|l|}{ Location (Base: village, less 3.000) } \\
\hline Small town (3.000 to 15.000$)$ & 0.0168 & $2.81^{* * *}$ & 0.0163 & $2.87 * * *$ & 0.0051 & $2.17^{* *}$ \\
\hline Town $(15.000$ to 100.000$)$ & 0.0325 & $5.11 * * *$ & 0.0369 & $6.08 * * *$ & 0.0372 & $3.85^{* * * *}$ \\
\hline City (100.000 to 1.000 .000$)$ & 0.0301 & $4.06^{* * * *}$ & 0.0361 & $4.92 * * *$ & 0.0359 & $3.68^{* * *}$ \\
\hline \multirow{2}{*}{\multicolumn{7}{|c|}{ School type (Base: private government dependent) }} \\
\hline & & & & & & \\
\hline Public & -0.0108 & -1.24 & -0.0040 & -0.17 & -0.1259 & -1.60 \\
\hline Private, government independent & 0.0450 & $3.28^{* * * *}$ & 0.2387 & $5.24 * * *$ & 0.2591 & $4.15^{* * * *}$ \\
\hline School size / number of teachers ratio & 0.0011 & $2.17 * *$ & 0.0029 & $5.64 * * *$ & 0.0017 & $3.89^{* * * *}$ \\
\hline \multicolumn{7}{|l|}{ Country characteristics } \\
\hline Log GDP per capita constant prices 2000 & -0.1741 & $-2.10^{* *}$ & -0.0596 & -0.62 & -0.1370 & $-1.69 *$ \\
\hline Log GDP per capita constant prices 2000 , squared & -0.0010 & -0.86 & -0.0167 & $-4.67 * * *$ & -0.0181 & $-4.39 * * *$ \\
\hline Log expenditure per student & -0.0887 & $-2.59 * *$ & -0.0961 & $-2.75 * * *$ & -0.0855 & $-2.39 * *$ \\
\hline Teacher salary at upper secondary education & $8.911 \mathrm{e}-06$ & $3.17 * * *$ & $9.317 \mathrm{e}-06$ & $2.97 * * *$ & $1.26 \mathrm{e}-6$ & $3.22 * * *$ \\
\hline Total expenditure in education as $\%$ of GDP & -0.0313 & $-3.61 * * *$ & -0.0209 & $-2.61 * * *$ & -0.0167 & $-1.90 *$ \\
\hline Unemployment rate $15-24$ years & 0.0061 & $5.40 * * *$ & 0.0044 & $3.26 * * *$ & 0.0024 & $2.12 * *$ \\
\hline Corruption index & 0.0045 & $7.05^{* *}$ & 0.0055 & $6.72^{* * * *}$ & 0.0019 & 2.50 ** \\
\hline \multicolumn{7}{|l|}{ Year (Base: 2000) } \\
\hline 2003 & 0.5987 & $3.57 * * *$ & 0.6370 & $3.46^{* * * *}$ & 0.1753 & 0.83 \\
\hline 2006 & 0.6030 & $3.57 * * *$ & 0.6311 & $3.41^{* * * *}$ & 0.2023 & 0.96 \\
\hline 2009 & 0.5695 & $3.34 * * *$ & 0.5665 & $3.02 * * *$ & 0.1916 & 0.21 \\
\hline
\end{tabular}

Significant at $* * * 1 \%, * * 5 \%$ and $* 10 \%$ level 
Table 7 (continuation)

\begin{tabular}{|c|c|c|c|c|c|c|}
\hline & \multicolumn{2}{|c|}{ Math achievement } & \multicolumn{2}{|c|}{ Reading achievement } & \multicolumn{2}{|c|}{ Science achievement } \\
\hline & Coefficient & t-stat & Coefficient & t-stat & Coefficient & t-stat \\
\hline \multicolumn{7}{|l|}{$\begin{array}{l}\text { Decentralization indexes } \\
\text { Political decentralization }\end{array}$} \\
\hline Self-rule (SR) ID+PS+FA+RP & 0.0141 & $3.70^{* * * *}$ & -0.0045 & -1.11 & 0.0012 & 0.28 \\
\hline Shared rule (SHR) $\mathrm{LM}+\mathrm{EC}+\mathrm{FC}+\mathrm{CR}$ & -0.0182 & $-2.68 * * *$ & -0.0073 & -1.03 & -0.0063 & -0.80 \\
\hline Average R-Squared & & 0.2046 & & 0.2122 & & 0.1534 \\
\hline Sample size & & 437.105 & & 432.994 & & 437.108 \\
\hline \multicolumn{7}{|l|}{ Fiscal decentralization } \\
\hline Sub-national Government Expenditure & 1.0863 & $4.78^{* * * *}$ & 0.6415 & $2.43 * *$ & 0.7039 & $2.68 * * *$ \\
\hline Sub-national Current Expenditure & 0.4519 & $2.72^{* * * *}$ & 0.4820 & $2.56 * *$ & 0.4221 & $2.47 * *$ \\
\hline Sub-national Capital Expenditure & 0.6072 & $5.79^{* * * *}$ & -0.0536 & -0.47 & -0.0249 & -0.15 \\
\hline Sub-national Revenue & 1.3064 & $5.49^{* * * *}$ & 1.0480 & $3.88 * * *$ & 0.8878 & $3.25 * * *$ \\
\hline Sub-national Tax Revenue & 1.3096 & $8.11^{* * * *}$ & 0.3111 & $1.76^{*}$ & 0.3477 & 1.42 \\
\hline Average R-Squared & & 0.2085 & & 0.2142 & & 0.1556 \\
\hline Sample size & & 393.796 & & 389.687 & & 393.799 \\
\hline
\end{tabular}

